\title{
A magyar háztartások portfólió választási preferenciái az időskorban
}

\author{
Tóth-Pajor Ákos \\ Pécsi Tudományegyetem
}

\begin{abstract}
A TANULMÁNY CÉLJA
A tanulmány célja a magyar háztartások portfólióválasztási szokásainak vizsgálata a nyugdíjkorhatárt elérő 65-80 éves korosztályban. Arra a kutatási kérdésre kerestem a választ, hogy a vizsgált korosztályba tartozó válaszadók milyen preferenciák szerint választják ki a számukra megfelelő portfóliót, hiszen a portfólió választás életciklus elmélete a nyugdíjkorhatárt elérő korosztály tekintetében nem vezet egyértelmü következtetésre.
\end{abstract}

\begin{abstract}
ALKALMAZOTT MÓDSZERTAN
A portfólióválasztás életciklus elméletéből következő, empirikusan is jól tesztelhető kutatási kérdés megválaszolása érdekében egy ordinális logisztikus regressziós modell segítségével vizsgáltam meg a portfólió választási szokásokat az életciklus különböző szakaszaiban az iskolai végzettség és a kockázati magatartás függvényében.
\end{abstract}

\begin{abstract}
A KUTATÁS LEGFONTOSABB EREDMÉNYEI, ÚJDONSÁGOK
Megállapítottam, hogy az iskolai végzettség és a kockázati magatartás hatásait kiszürve a 65-80 éves korosztályba tartozók szignifikánsan nagyobb valószínűséggel választanak kevésbé kockázatos portfóliókat a fiatalabbakhoz képest. Ezen felül megmutattam, hogy a részvényeket nem tartalmazó portfóliókat választók körében a 65-80 éves korosztály aránya szignifikánsan magasabb.
\end{abstract}

\section{GYAKORLATI JAVASLATOK}

A tanulmányban bemutatott eredmények iránymutatásként szolgálnak a magyar háztartások nyugdíjkorhatárt követő életszakaszban megfigyelhető portfólióválasztási szokásainak vonatkozásában, ezzel kiegészítve a portfólió választás életciklus elméletének következtetéseit.

Kulcsszavak: portfólióválasztás, időskor, kockázati magatartás

Köszönetnyilvánitás: A tanulmány az „EFOP-3.6.1-16-2016-00004. Átfogó fejlesztések a Pécsi Tudományegyetemen az intelligens szakosodás megvalósitása érdekében (Időskori döntéshozatal projektelem, 11. téma) " címủ pályázat támogatásával készült.

DOI: 10.15170/MM.2021.55.KSZ.02.04 


\section{BEVEZETÉS INTRODUCTION}

A tanulmány célja a magyar háztartások portfólió választási szokásainak vizsgálata az időskorban. A tanulmányban arra kutatási kérdésre keressem a választ, hogy miként alakul a háztartások portfólió választása Magyarországon a nyugdíjkorhatárt követő életszakaszban.

A háztartások időskori megtakarítási szokásai egy demográfiai tényezök szerint reprezentatív 800 fős megkérdezéses módszertan (kérdező biztos segít a kérdőivet végig vinni) segítségével kerül bemutatásra, amely kérdőív kitér a megkérdezettek portfólió választási szokásai (hogy kockázat alapján milyen portfóliót választanak), kockázati magatartása és a különböző szociológia háttérváltozók feltárására. A feltett kérdések Guillemette et al. (2012) munkáján alapulnak, akik a kockázati magatartás és a portfólióválasztás kapcsolatát vizsgálták különbözö kockázati attitüd mértékek szerint. Guillemette et al. (2012) munkájával szemben jelen kutatás az életpálya szerint megfigyelhető különbségekre koncentrál kohorszok szerint csoportosítva a válaszadókat és egy adott portfólió kiválasztásának bekövetkezési valószínűségét számszerüsíti a döntéshozók megfigyelhető tulajdonságai alapján.

A kutatás rámutat, hogy a 65-80 éves korosztályban a válaszadók szignifikánsan nagyobb valószínűséggel választanak kevésbé kockázatos portfóliókat, mint a fiatalabb korosztályokba tartozó válaszadók. A részvényeket nem tartalmazó portfóliókat választók körében a 65-80 éves korosztály aránya szignifikánsan nagyobb. Az eredményeket árnyalja, hogy kohorszokon belül a kockázati magatartásban megfigyelhető heterogenitás szignifikáns különbségeket eredményezhet a portfólió választásban. A kutatás során bemutatott empirikus megfigyelések a magyar háztartások tekintetében iránymutatást adnak a portfólió választás életciklus elméletének vonatkozásában a nyugdíjkorhatárt követő életszakaszokban.

A tanulmányban elsőként a háztartások portfólió választásához kapcsolódó releváns szakirodalmat tekintem át. Ezután leíró jelleggel bemutatom a vizsgált mintát és a portfólió választást befolyásoló tényezőket, majd a portfólió választás különbségeit vizsgálom meg az életpálya mentén, különös tekintettel az időskori döntésekre. Végül értékelem a kutatási kérdéshez kapcsolódó eredményeket és levonom a következtetéseket.

\section{SZAKIRODALMI ÁTTEKINTÉS LITERATURE REVIEW}

A háztartások portfólió választása egy széles körben kutatott téma, amely a hasznosság elvű döntéshozatal keretrendszerén alapszik, de egyre inkább a szociológia és kognitív pszichológia tényezők vizsgálatának és empirikus kérdőives felmérések használatának irányába mozdul el. A tanulmányok többsége arra a kérdésre keresi a választ, hogy miért szembetünő a kockázatos eszközök alulsúlyozása a háztartások által tartott portfóliókban (Zhan 2015). A korai tanulmányok a háztartásokat egyetlen egységnek tekintették és egy adott hasznossági függvényből kiindulva vizsgálták a portfólió választást. Ezek a tanulmányok a kockázatos eszközök alacsony súlyát belépési korlátoknak tulajdonították (Vissing-Jorgensen 2002, Cocco et al. 2005, Gomes \& Michaelides 2005, Alan 2006). A későbbi tanulmányok a háztartásokat heterogén egységeknek tekintették, amelyben a résztvevők közötti alkufolyamat határozza meg a portfólió választást (Arano et al. 2010, Yilmazer \& Lyons 2010, Bateman \& Munro 2005, Flinn et al. 2018, Bertocchi \& 2014, Yilmazer \& Lich 2015, Gu et al. 2019). A szociológia és kognitív pszichológia tényezőket vizsgáló tanulmányok továbbá rámutattak, hogy olyan tényezők, mint a kor, iskolai végzettség, jövedelmi helyzet, vagyon, családi állapot is szignifikánsan befolyásolhatják a háztartások portfólió választását (Campbell 2006, Curcuru et al. 2010, Friedberg \& Webb 2006, Bertocchi et al. 2014, Cooper \& Zhu 2016, Alhenawi \& Elkhal 2013). Ezen felül kapcsolatot találtak, még a pénzügyi műveltség, a személyiség jegyek, a kognitív képességek és portfólió választás között. (Elder \& Rudolph 2003, Johnston 2016, Smith et al. 2010, Clark et al. 2017, Van Rooij et al. 2011). Jia et al. (2019) rámutatnak, hogy a pénzügyi tervezéssel kapcsolatos tudás is fontos szerepet játszik a portfólió választásban. Campbell (2006) amellett érvel, hogy a szegényebb, kevésbé tanult döntéshozók többször hibáznak a befektetési döntéseik során. Dimmock \& Kouwenber (2010) megmutatják, hogy a veszteség kerülés szignifikánsan csökkenti a kockázatos eszközök tartását.

Cocco et al. (2005) háztartások portfólióválasztásának életciklus modelljét vizsgálva arra jutnak, hogy a nyugdíjas évekhez közeledve a háztartások egyre kevesebb kockázatos eszközt tartanak. A kockázatos eszközök súlya a nyugdíjig a munkajövedelem jelenértéke és a vagyon hányadosának alakulásától függ. Ezt a kapcsolatot továbbá befo- 
lyásolják a részvényhozamok és a munkajövedelem korrelációja, valamint a különböző szociológia és egészségügyi háttérkockázatok is.

Gomes et al. (2020) amellett érvel, hogy a nyugdijjkor elérését követően a kockázatos eszközök súlya attól függ, hogy a jövedelmek jelenértéke, vagy a vagyon csökken gyorsabban.

Choi \& Robertson (2020) amellett érvelnek, hogy a nyugdíjig hátralevő idő egy fontos tényező a portfólió választásban. Az egyszerü életciklus modell szerint a vagyon kockázatos eszközben tartott része a nyugdíjig csökken, míg a nyugdíjat követően nem lehet egyértelmüen következtetni a kockázatos eszközök súlyára. Azonban sok esetben konkáv függvényformát vehet fel vagy monoton növekvő lehet a kapcsolat a jövedelem-vagyon hányados és a kockázatos eszközök súlya között (Benzoni et al. 2007, Campanale et al. 2015, Fagereng et al. 2017, Bagliano et al. 2017).

A szakirodalom a kort tekintve három hatást különít el. A kohorszok, az életkor és a naptári év hatását. Mivel a születési dátum és a kor összege megadja a naptári évet, így a három hatás egyszerre nem vizsgálható. Az eredmények így sokszor a bevont hatásoktól is függnek. Poterba \& Samwick (1997) azt találta, hogy a kockázatos eszközök súlya 40 éves korban éri el a csúcsát. Ameriks \& Zeldes (2004) a különböző hatások vizsgálata során azt találta, hogy a kohorsz hatás esetén a kockázatos eszközök súlya 60 éves korig nő, aztán nem változik. A naptári évek hatását vizsgálva azonban 55 éves korig lapos és azután csökkenő. Guillemette et al. (2012) negatív kapcsolatot talál az életkor és a kockázatos eszközök tartása között. Catherine (2019) ezzel szemben lapos vagy enyhén növekvő mintázatokat talált.

A magyarországi vizsgálatok tekintetében elsőként Ulbert - Csanaky (2004) és Ulbert (2005) mutattak rá arra, hogy a döntéshozók kockázati magatartása időben nem stabilak és a döntéshozók nem konzekvensek a döntéseik során, így a hasznosságelvű döntéshozatal keretrendszere korlátozottan alkalmazható. Ehelyett a kockázati magatartást a kockázatészlelés hatékonysága határozza meg, amely visszavezethető szociológiai és kognitív pszichológiai tényezőkre. A kockázatészlelés hatékonyságában megfigyelhető eltérések alapján a kockázati magatartást tekintve homogén csoportok képezhetők. A kockázati attitüdmérés kognitív pszichológiai megközelítését igazolja, hogy habár a vizsgált döntéshozók nem teljesítették a racionalitási axiómákat, a befektetési preferenciáik illeszkedtek a kockázati magatartásukhoz. A szerzők azt találják, hogy a kockázati magatartást az életkor az iskolai végzettség, továbbá a jövedelmi helyzet is befolyásolja. Vasvári (2015) eredményei ezen állításokat kiegészítik azzal, hogy fontos szempont az is, hogy az egyén kockázatkezelési költsége ne legyen magasabb a tényleges kockázatnál, így a kockázati magatartás egy más aspektusát világítja meg.

Guillemette et al. (2012) a kockázati magatartás és a portfólióválasztás kapcsolatát vizsgálva háromféle kockázati magatartás mértéket is számszerüsít, amely szignifikánsan magyarázza a portfólió választást. Ezek a veszteségkerülésen alapuló mértékek, az önértékelésen alapuló mértékek és az Arrow-Pratt féle kérdések. Az Arrow-Pratt féle kérdések a jövedelem bizonytalanságát kevésbé toleráló döntéshozókat tekintik kockázat kerülőbbnek. A veszteségkerülést mérő kérdések a nagyobb mértékben veszteségkerülő döntéshozókat tekintik kockázat kerülőbbnek.

A magyar háztartások tekintetében Balogh és szerzőtársai (2019) a Household Finance and Consumption Survey (HFCS) adatainak vizsgálata során a kockázatos eszközök keresletében országok szerint megfigyelhető különbségeket elemezve arra a következtetésre jutottak, hogy a jövedelem, a vagyon, az iskolai végzettség és a kockázatvállalás pozitívan befolyásolja a kockázatos eszközök tartását. A szerzők Magyarországot a kevésbé aktív tőkepiaci kereslettel rendelkező országok közé sorolják és az életkor szerint nem azonosítanak szignifikáns különbségeket. Boldizsár és szerzőtársai (2016) ugyanezt az adatbázist vizsgálva rámutatnak, hogy a magyar háztartások többségének a legfontosabb vagyontárgya a lakóingatlan, legtöbbször ennek megszerzése érdekében takarítanak meg vagy adósodnak el a háztartások.

A szakirodalmi áttekintés alapján érdekes, empirikusan tesztelhető kutatási kérdés, hogy a magyar háztartások esetében a nyugdíjkorhatáron túli, vagy Posza (2019) alapján idős, 65-80 éves korosztályban milyen portfólió választási szokásokat figyelhetünk meg. A portfólió választás életciklus elmélete a nyugdijkkorhatár elérését követően nem vezet egyértelmü következtetésre, így a nyugdíjkorhatárt elérő 65-80 éves korosztály választásainak vizsgálata iránymutatást adhat a portfólióválasztás tekintetében az életciklus nyugdíjkorhatárt követő szakaszában. Kuti és Schepp (2020) nemzetközi szakirodalmat szintetizáló munkája alapján, a kockázatvállalási hajlandóság csökken idősebb korban. Elözetes várakozásaink alapján az alábbi hipotézist fogalmaztam meg: 1. A 65-80 éves kohorszba tartozó válaszadók nagyobb valószínüséggel választanak alacsonyabb kockázat-hozam aránnyal rendelkezö portfóliókat, mint a fiatalabb válaszadók. 


\section{MINTA ÉS LEÍRÓ SZTATISZTI- KÁK \\ SAMPLE AND DESCRIPTIVE STATISTICS}

A portfólióválasztás vizsgálatához szükséges adatokat az EFOP 3.6.1 pályázat időskori döntéshozatalt vizsgáló kutatásához készült 800 fös reprezentatív kérdőív gyüjtötte össze. A kérdőív kérdezőbiztos segítségével kerül lekérdezésre. Ezen módszerrel az egyszerü kérdőíves lekérdezésnél szenzitívebb és pontosabb adatokat kaphatunk, mivel a kérdezőbiztos szükség esetén feltárja a kockázatokat az alanyok elött. A lekérdezést a Szocio-Gráf Piac- és Közvélemény-kutató Intézet készítette. Az egyes kérdésekre nem válaszolók kiszürése után 596 kitöltés alapján tudtam elemezni a portfólióválasztást és az azt befolyásoló tényezőket. A kérdőív a portfólió választásra Guillemette et al. (2012) munkája alapján kérdez rá. A kérdőívek kitöltői a Melléklet 1. táblázatában szereplő, hipotetikus portfóliók közül választhattak. A kérdezőbiztos feltette a táblázatban szereplő kérdést, majd a választási lehetőségeket egy kártyán adta át, és ha kellett elmagyarázta a döntéshozóknak a portfóliók közötti különbségeket. A kérdés szerint a válaszadók 7 portfólió közül választhattak, amelyekben különböző súlyokkal szerepeltek alacsony, közepes és magas kockázat-hozam arányú befektetési lehetőségek. A portfóliókban szereplő eszközöket iránymutatásul meg is nevezte a kérdöív.

Az adatbázis alapjául szolgáló kérdőív rákérdezett a kitöltők kockázathoz való viszonyára (Melléklet 2. táblázat) különböző szakirodalmakból ismert, veszteségkerülésre és önértékelésre alapozó kockázati magatartás mérésére alkalmas kérdésekkel, valamint felmérte a kitöltök szociológiai helyzetét. A kérdőívekben feltett kérdések úgy kerültek kialakításra, hogy ordinális változók segítségével tudjuk megvizsgálni a portfólió választást és az azt befolyásoló tényezőket.
A kérdések kiértékelése során további változók is definiálásra kerültek. A kockázati magatartást vizsgáló kérdések esetében a Melléklet 2. táblázatában szereplő B2, B3 és B4 kérdésekre adott válaszok szorzataként egy további kockázati magatartást megragadó mérőszámot (Risk) is definiáltam. Az így kialakított méröszámhoz tartozó Cronbach alfa érték 0,73. Mivel a Cronbach alfa értékét 0,700,85 között tartja elfogadhatónak a szakirodalom, a jelenlegi érték arra utal, hogy a változóba bevont kérdések ugyanazt a jelenséget ragadják meg.

A szociológiai helyzet jellemzésére alkalmas kérdések tekintetében, megkérdezésre került a kitöltők neme, kora, iskolai végzetsége, jövedelmi helyzete és az egy háztartásban élők száma (Melléklet 3. táblázat).

Az 1. táblázatban az ordinális változók leíró statisztikáit közlöm. A változók esetén a csoportok mintán belüli arányait mutatom be. A B1- es kérdés esetében a válaszadók többsége általában a lehetséges nyereségekre koncentrál. A B2-es kérdés esetében ezzel szemben a válaszadók többségét kényelmetlenül érintenék a veszteségek. A B3 és B4 alapján a többség nem szeret nagy kockázatot vállalni. A B5 kérdésre adott válaszok alapján egyértelmủen az látszik, hogy a válaszadók $73 \%$ választ olyan portfóliót, amelyben a részvények súlya $10 \%$ vagy alacsonyabb, és $51,7 \%$ választ olyan portfóliót, amelyben egyáltalán nincsenek részvények. A válaszadók többségének a legmagasabb végzettsége szakmunkásképző vagy érettségi. A többség 2 vagy 3 fös háztartásban él. A kockázati magatartás mérték (Risk) esetében a nagyobb érték nagyobb kockázatvállalási hajlandóságot mutat. A változó esetében a medián kisebb mint az átlag, amiből arra következtethetünk, hogy sürübben fordulnak elő alacsonyabb értékek, a változóra jobb oldali ferdeség jellemző. 
1. táblázat: Leíró statisztikák

Table 1. Descriptive statistics

\begin{tabular}{l|llllllll}
$\mathbf{\%}$ & $\mathbf{1}$ & $\mathbf{2}$ & $\mathbf{3}$ & $\mathbf{4}$ & $\mathbf{5}$ & $\mathbf{6}$ & $\mathbf{7}$ & $\begin{array}{l}\text { Megfi- } \\
\text { gyelések } \\
\text { száma }\end{array}$ \\
\hline B1 & 16,4 & 21,8 & 45,8 & 15,9 & NA & NA & NA & 596 \\
B2 & 51,7 & 25,8 & 13,4 & 4,7 & 3,0 & 1,3 & NA & 596 \\
B3 & 29,2 & 30,2 & 34,7 & 4,7 & 1,2 & NA & NA & 596 \\
B4 & 33,6 & 31,5 & 32,4 & 2,3 & 0,2 & NA & NA & 596 \\
B5 & 32,6 & 19,1 & 21,3 & 14,8 & 9,7 & 2,0 & 0,5 & 596 \\
SZ1 & 18,8 & 15,6 & 20,1 & 23,7 & 21,8 & NA & NA & 596 \\
H1 & 51,3 & 48,7 & NA & NA & NA & NA & NA & 596 \\
H2 & 13,9 & 31,0 & 43,0 & 12,1 & NA & NA & NA & 596 \\
H3b & 2,3 & 12,6 & 19,6 & 12,8 & 28,5 & 24,2 & NA & 596 \\
H5 & 18,0 & 36,4 & 21,1 & 18,3 & 3,9 & 2,0 & 0,3 & 596 \\
\hline & Átlag & Szórás & Standard & Minimum & Medián & Maximum & & Megfi- \\
& & & hiba & & & & & gyelések \\
& & & & & & & & \\
\hline Risk & 11,065 & 12,53 & 0,513 & 1 & 8 & 80 & & 596
\end{tabular}

Forrás: saját szerkesztés

A 2. táblázatban a portfólió választás kohorszok szerinti különbségeit mutatom be a 800 fös reprezentatív minta alapján szürt 596 fơs adatállomány kapcsán abban az esetben, amikor a részvényt nem tartalmazó portfóliókat választó döntéshozókat különítem el a részvényt tartalmazó portfóliókat választóktól. Ezt a két csoportot osztottam fel kohorszok szerint és megvizsgáltam, hogy megfigyelhetők-e szignifikáns különbségek a csoportok kohorszok szerinti összetétele alapján. Kiszámítottam a csoporton belüli arányok közötti különbségeket és két-mintás arányteszt segítségével megmutattam a szignifikáns különbségeket. A különbség oszlopban a szignifikancia szinteket csillaggal jelöltem, míg zárójelben a próbastatisztika értéke szerepel. A 2. táblázatban jól látható, hogy egyedül a 65-80 éves korosztály esetében figyelhetünk meg $1 \%$-os szignifikancia szinten szignifikáns különbségeket. A 65-80 éves korosztály aránya a részvényeket nem tartalmazó portfóliókat választók körében 9,3\%-al nagyobb, mint a részvényeket tartalmazó portfóliók körében. Ez arra utal, hogy a magyar háztartások esetében a 65-80 éves korosztály a kevésbé kockázatos portfóliókat preferálja, amelyekben csak ingatlan és kötvények vannak. Ez az eredmény egyértelmüen rámutat a nyugdíjkorhatárt elérő 65-80 éves korosztály portfólió választási szokásaira. Ezen felül 10\%-os szinten szignifikáns különbséget figyelhetünk meg a 40-49 éves korosztály esetében. A 41-49 éves korosztály aránya a részvényeket nem tartalmazó portfóliókat választók körében $6,1 \%$-al alacsonyabb, mint a részvényeket tartalmazó portfóliókat választók esetén. Ebből arra következtethetünk, hogy a 40-49 éves korosztály esetében nagyobb a hajlandóság a kockázatos portfóliók választására. 


\section{2. táblázat: Portfólióválasztás a kohorszok szerint}

Table 2. Portfolio choice across cohorts

\begin{tabular}{l|cccc}
\multicolumn{1}{c|}{$\%$} & Portfólió1-2 & Portfólió3-7 & Teljes minta & Különbség \\
\hline $18-29$ & 18,8 & 18,8 & 18,8 & $0,0(0,000)$ \\
$30-39$ & 14,0 & 17,4 & 15,6 & $-3,4(1,061)$ \\
$40-49$ & 17,2 & 23,3 & 20,1 & $-6,1 *(3,028)$ \\
$50-64$ & 23,7 & 23,6 & 23,7 & $0,1(0,000)$ \\
$65-80$ & 26,3 & 17,0 & 21,8 & $9,3 * * *(6,989)$ \\
\hline Teljes minta & 51,7 & 48,3 & 100 & 3,4 \\
$* * * \mathrm{p}<0,01, * * \mathrm{p}<0,05, * \mathrm{p}<0,1$ & & &
\end{tabular}

Forrás: saját szerkesztés

\section{PORTFÓLIÓ VÁLASZTÁS AZ ÉLETCIKLUS KÜLÖNBÖZŐ SZAKASZAIBAN A KOCKÁZATI MAGATARTÁS ÉS AZ ISKOLAI VÉGZETTSÉG FÜGGVÉNYÉBEN PORTFOLIO CHOICE IN THE DIFFERENT PHASES OF LIFE CYCLE ACCORDING EDUCA- TION AND RISK BEHAVIOR}

A portfólió választás életciklus modellje szerint a kockázatos eszközök súlya az életciklus elöre haladtával csökken, majd a nyugdíjkorhatárt elérve nem lehet egyértelmü következtetéseket tenni (Gomes et al. 2020). Ennek okán egy érdekes, empirikusan tesztelhető kutatási kérdés, hogy a magyar háztartások esetében hogyan alakul a portfólió választás a nyugdíjkorhatár felett a 65-80 éves korosztályban. A kutatási kérdés megválaszolása érdekében egy ordinális logisztikus regressziós modell segítségével vizsgáltam meg, a portfólió választási szokásokat az életciklus különböző szakaszaiban. A kohorszok szerinti különbségek vizsgálata során figyelembe vesszem a kockázati magatartás és az iskolai végzettség esetében megfigyelhető heterogenitást és ezeket figyelembe véve vizsgálom meg a kohorszok és a portfólióválasztás kapcsolatát az (1) egyenletben található saját modell alapján.

$$
\operatorname{logit}[P(B 5 \leq j)]=\ln \left[\frac{P(B 5 \leq j)}{P(B 5>j)}\right]=\alpha_{j}-\beta_{1} * S Z 1-\beta_{2} * S Z 1 * \text { Risk }-\beta_{3} * S Z 1 * H 2
$$

,ahol $j=1, \ldots, 6$ a választható portfóliókat, $\mathrm{B} 5$ a portfólió választásokat jelöli, $P(B 5 \leq j)$ annak a kumulált valószínüsége, hogy a válaszadó j-edik portfóliót vagy attól kevésbé kockázatos portfóliót választ, és logit $[P(B 5 \leq j)]$ az esélyhányados logaritmusát, $\alpha_{j}$ a portfóliónként változó tengelymetszetet, SZ1 a kohorszokat, Risk a kockázati magatartást megragadó mértéket, $\mathrm{H} 2$ az iskolai végzettséget, $\beta$ a regressziós paramétereket jelöli. A modellben a kohorszokhoz tartozó paraméter a kockázati magatartás és az iskolai végzettség függvényében változhat, így a kohorszok és a portfólióválasztás kapcsolatát leíró egyenlet meredeksége a $\left(\beta_{1}+\beta_{2} *\right.$ Risk $\left.+\beta_{3} * H 2\right)$ összefüggés alapján határozható meg a kockázati magatartás és az iskolai végzettség függvényében. Hiszen az (1) egyenletben szereplő modellt a (2) látható módon átrendezhetjük. 


$$
\operatorname{logit}[P(B 5 \leq j)]=\ln \left[\frac{P(B 5 \leq j)}{P(B 5>j)}\right]=\alpha_{j}-\left(\beta_{1}+\beta_{2} * \text { Risk }+\beta_{3} * H 2\right) * S Z 1
$$

Az 3. táblázatban az (1) egyenlet alapján becsült ordinális logisztikus regressziós modell eredményeit mutatom be. A modell esetében az McFadden R2 5,7\% a Nagelkerke R2 16,9\%, a modell az esetek $38,1 \%$-át sorolja be helyesen. A Wald típusú Khi-négyzet próbák eredményei továbbá azt mutatják, hogy a bevont változók mind szignifikán- san javítják a modell illeszkedését. A Wald próbák szignifikancia értékeit a próbaérték mellett feltüntetett csillagok jelölik. A kohorszok esetében a 65-80 éves korosztály a referencia csoport, míg az iskolai végzettség esetében a felsőfokú végzettségüek. A paraméterek mellett zárójelben a standard hibákat szerepeltetem.

\section{3. táblázat: Portólióválasztás a kohorszok szerint a kockázati magatartás és az iskolai végzettség függvényében}

Table 3. Portfolio choice across cohorts as a function of risk behavior and education

\begin{tabular}{|c|c|c|c|}
\hline \multirow{2}{*}{$\begin{array}{l}\text { Eredmény változó: B5 } \\
\text { SZ1: } 65-80\end{array}$} & \multicolumn{3}{|l|}{ Model1 } \\
\hline & Paraméter & SZ1*Risk4 & Paraméter \\
\hline $18-29$ & $2,133 * * *(0,757)$ & $18-29 *$ Risk4 & $0,012(0,013)$ \\
\hline $30-39$ & $1,393 *(0,748)$ & 30-39*Risk4 & $0,052 * * *(0,016)$ \\
\hline $40-49$ & $1,998 * * *(0,745)$ & 40-49*Risk4 & $0,033 * * *(0,012)$ \\
\hline \multirow[t]{2}{*}{$50-64$} & $1,719 * *(0,719)$ & 50-64*Risk4 & $0,057 * * *(0,014)$ \\
\hline & & $65-80 *$ Risk4 & $0,067 * * *(0,014)$ \\
\hline $\mathrm{SZ} 1 * \mathrm{H} 2: 4$ & Paraméter & $\mathrm{SZ} 1 * \mathrm{H} 2: 4$ & Paraméter \\
\hline $18-29 * 1$ & $-1,230 *(0,709)$ & $18-29 * 2$ & $-0,820(0,677)$ \\
\hline $30-39 * 1$ & $-1,611 * *(0,727)$ & $30-39 * 2$ & $-0,901(0,550)$ \\
\hline $40-49 * 1$ & $0,637(0,749)$ & $40-49 * 2$ & $-1,066^{* *}(0,532)$ \\
\hline $50-64 * 1$ & $-0,448(0,635)$ & $50-64 * 2$ & $-1,353 * * *(0,506)$ \\
\hline $65-80 * 1$ & $-0,435(0,656)$ & $65-80 * 2$ & $0,707(0,609)$ \\
\hline $\mathrm{SZ} 1 * \mathrm{H} 2: 4$ & Paraméter & & \\
\hline $18-29 * 3$ & $-0,919 *(0,544)$ & & \\
\hline $30-39 * 3$ & $-0,451(0,512)$ & & \\
\hline $40-49 * 3$ & $-0,575(0,520)$ & & \\
\hline $50-64 * 3$ & $-0,790(0,482)$ & & \\
\hline $65-80 * 3$ & $1,042 *(0,602)$ & & \\
\hline \multicolumn{4}{|l|}{ Portfólió választás } \\
\hline Portfólió1|Portfólió2 & $0,592(0,554)$ & Portfólió2|Portfólió3 & $1,504 * * *(0,557)$ \\
\hline Portfólió3|Portfólió4 & $2,579 * * *(0,562)$ & Portfólió4|Portfólió5 & $3,660 * * *(0,572)$ \\
\hline Portfólió5|Portfólió6 & $5,450 * * *(0,627)$ & Portfólió6|Portfólió7 & $7,179 * * *(0,831)$ \\
\hline $\mathrm{AIC}$ & 1887,595 & $\mathrm{BIC}$ & 2019,303 \\
\hline Log Likelihood & $-913,798$ & Num, obs, & 596 \\
\hline McFadden R2 & 0,057 & Nagelkerke R2 & 0,169 \\
\hline SZ1 Wald $\chi^{2}$ próba & $21.738 * * *$ & $\mathrm{SZ} 1 *$ Risk Wald $\chi^{2}$ próba & $37.532 * * *$ \\
\hline $\mathrm{SZ} 1 * \mathrm{H} 2$ Wald $\chi 2$ próba & $54.864 * * *$ & Helyes besorolás & 0,381 \\
\hline \multicolumn{4}{|c|}{ Megjegyzés: Standard hibák a zárójelben } \\
\hline
\end{tabular}

Forrás: saját szerkesztés 
A 4. táblázatban a modellbecslés eredményeit a paraméterbecslések alapján számolt esélyhányadosok segítségével értelmezem. Az esélyhányadosok esetén az 1 feletti érték arra utal, hogy a válaszadók a kevésbé kockázatos portfóliókat preferelják, míg 1 alatti érték esetén a kockázatosabb portfóliókat részesítik előnyben. A portfólióválasztásra vonatkozó esélyhányadosok 1 feletti értéke megmutatja, hogy a válaszadók alapvetően nagyobb valószínűséggel választanak a kevésbé kockázatos portfóliók közül. Elsőként a $\frac{P(B 5 \leq 2)}{P(B 5>2)}$ esélyhányados szignifikáns, amelyből kiszámítva a $P(B 5 \leq 2)$ valószínűséget $81,8 \%$-ot kapunk. Ceteris paribus ekkora a valószínüsége, hogy a modell szerint a válaszadók részvényeket nem tartalmazó portfóliókat választanak. A referenciakategóriákhoz mért esélyhányadosokat elemezve az is jól látható, hogy az iskolai végzettség és a kockázati magatartás hatását figyelmen kívül hagyva a 65-80 éves korosztályhoz képest minden más korosztály kockázatosabb portfóliókat választana. Ez az esélyhányados a 18-29 és 40-49 éves korosztályban 1\% szinten szignifikáns, az 50-64 éves korosztályban 5\%-on szignifikáns, míg a 30-39 éves korosztályban csak 10\%-os szinten szignifikáns. A modell alapján továbbá érdekes megfigyelés, hogy a 18-29 éves és a 30-39 éves korosztályban a felsőfokú végzettséggel rendelkezőkhöz képest a legfeljebb 8 általánossal rendelkezők a kevésbé kockázatos portfóliókat preferálják. Az esélyhányados a 18- 29 éve korosztályban 10\%-os szinten míg a 30-39 éves korosztályban 5\%-os szinten szignifikáns. Ugyanez igaz a szakmunkás képzővel rendelkezőkre a 40-49 és a 50-64 éves korosztályban. Emellett jól látható, hogy a kockázati magatartást is figyelembe véve a 30-80 közöttiek esetében a kockázati magatartás mérték növekedése kockázatosabb portfólióválasztásokat eredményez. Ezekben az esetekben az esélyhányados 1 alatt van és $1 \%$-os szinten szignifikáns.

\section{4. táblázat: A paraméterbecslés alapján számolt esélyhányadosok Table 4. Odds ratios computed according to the parameter estimations}

\begin{tabular}{|c|c|c|c|}
\hline Változó & Esélyhányados & Alsó95\% & Felső95\% \\
\hline Portfólió1|Portfólió2 & 1,808 & 0,610 & 5,358 \\
\hline Portfólió2|Portfólió3 & $4,499 * * *$ & 1,511 & 13,393 \\
\hline Portfólió3|Portfólió4 & $13,181^{* * *}$ & 4,379 & 39,676 \\
\hline Portfólió4|Portfólió5 & $38,867 * * *$ & 12,656 & 119,364 \\
\hline Portfólió5|Portfólió6 & $232,792 * * *$ & 68,161 & 795,064 \\
\hline Portfólió6|Portfólió7 & $1312,229 * * *$ & 257,411 & 6689,469 \\
\hline $18-29$ & $0,118 * * *$ & 0,523 & 0,027 \\
\hline $30-39$ & $0,248^{*}$ & 1,077 & 0,057 \\
\hline $40-49$ & $0,136^{* * *}$ & 0,584 & 0,032 \\
\hline $50-64$ & $0,179 * *$ & 0,733 & 0,044 \\
\hline 18-29*Legfeljebb 8 általános & $3,421 *$ & 13,734 & 0,852 \\
\hline 30-39*Legfeljebb 8 általános & $5,005^{* *}$ & 20,795 & 1,205 \\
\hline 40-49*Legfeljebb 8 általános & 0,529 & 2,295 & 0,122 \\
\hline 50-64*Legfeljebb 8 általános & 1,565 & 5,438 & 0,451 \\
\hline 65-80*Legfeljebb 8 általános & 1,545 & 5,587 & 0,427 \\
\hline 18-29*Szakmunkásképző, szakiskola & 2,270 & 8,548 & 0,603 \\
\hline 30-39*Szakmunkásképző, szakiskola & 2,462 & 7,239 & 0,838 \\
\hline 40-49*Szakmunkásképző, szakiskola & $2,904 * *$ & 8,238 & 1,024 \\
\hline 50-64*Szakmunkásképző, szakiskola & $3,870^{* * *}$ & 10,424 & 1,437 \\
\hline 65-80Szakmunkásképző, szakiskola & 0,493 & 1,627 & 0,150 \\
\hline
\end{tabular}




\begin{tabular}{l|lll} 
18-29*Érettségi & $2,506^{*}$ & 7,275 & 0,863 \\
$30-39 *$ Érettségi & 1,571 & 4,281 & 0,576 \\
$40-49 *$ Érettségi & 1,777 & 4,927 & 0,641 \\
$50-64 *$ Érettségi & 2,204 & 5,668 & 0,857 \\
$65-80 *$ Érettségi & $0,353^{*}$ & 1,148 & 0,108 \\
$18-29 *$ Risk & 0,988 & 1,015 & 0,963 \\
$30-39 *$ Risk & $0,949^{* * *}$ & 0,979 & 0,920 \\
$40-49 *$ Risk & $0,967 * * *$ & 0,991 & 0,944 \\
$50-64 *$ Risk & $0,945^{* * *}$ & 0,972 & 0,919 \\
$65-80 *$ Risk & $0,936^{* * *}$ & 0,961 & 0,911 \\
\hline
\end{tabular}

$* * * \mathrm{p}<0,01,{ }^{* *} \mathrm{p}<0,05,{ }^{*} \mathrm{p}<0,1$

Forrás: saját szerkesztés

Az 5. táblázatban a portfólió választás kohorszok szerinti különbségei figyelhetők meg a modell becsléseiből következő portfólióválasztások szerint abban az esetben, amikor a részvényt nem tartalmazó portfóliókat választó döntéshozókat különítjük el a részvényt tartalmazó portfóliókat választóktól. A különbségek vizsgálata a 2. táblázatnál ismertetett módszereken alapul. A különbségeket két mintás arányteszt segítségével vizsgáltuk meg. A különbség oszlopban, zárójelben a próbastatisztikákat szerepeltetjük, míg csillagokkal a szignifikancia értékeket jelöljük. A táblázat alapján megfigyelhető, hogy a részvényeket nem tartalmazó portfóliókat választók körében szignifikánsan nagyobb a 18-29 éves és a 65-80 éves korosztály aránya. Elöbbi esetben 9,1\% a különbség, míg utóbbi esetben $13,4 \%$. Ezek az értékek magyarázhatók a fiatalok alacsony mértékü megtakarításaival, illetve a nyugdíjkorhatár felettiek öngondoskodási törekvéseivel. Egyedül a 40-49 éves korosztályban figyelhetünk meg szignifikánsan alacsonyabb arányt a részvényeket nem tartalmazó portfóliókat választók között. Az eredményből jól látható, hogy az iskolai végzettség és a kockázati magatartás hatásait is figyelembe véve az életciklus elején a válaszadók kockázatkerülőbbek, majd a 40-49 éves korosztályban inkább a kockázatos portfóliókat preferálják, míg a nyugdíjkorhatár elérését követően a kockázatvállalási hajlandóság ismét szignifikánsan csökken.

\section{5. táblázat: Portfólióválasztás az életciklus különböző szakaszaiban a kockázati magatartás és az iskolai végzettség szerint}

Table 5. Portfolio choice in the life cycle according to risk behavior and education

\begin{tabular}{|c|c|c|c|c|}
\hline$\%$ & Portfólió1-2 & Portfólió3-7 & Teljes minta & Különbség \\
\hline $18-29$ & 21,5 & 12,4 & 18,8 & $9,1 * *(6,293)$ \\
\hline $30-39$ & 14,1 & 19,1 & 15,6 & $-5,0(1,994)$ \\
\hline $40-49$ & 14,1 & 34,3 & 20,1 & $-20,2 * * *(30,296)$ \\
\hline $50-64$ & 24,4 & 21,9 & 23,7 & $2,5(0,302)$ \\
\hline $65-80$ & 25,8 & 12,4 & 21,8 & $13,4 * * *(12,518)$ \\
\hline Teljes minta & 70,1 & 29,9 & 100 & 40,2 \\
\hline
\end{tabular}

Forrás: saját szerkesztés 


\section{KÖVETKEZTETÉSEK CONCLUSIONS}

A tanulmányban a magyar háztartások portfólió választási szokásait vizsgáltam az életciklus szerint. A portfólióválasztás életciklus modellje szerint érdekes, empirikusan vizsgálható kutatási kérdés, hogy a nyugdíjkorhatár elérését követően milyen portfóliókat választanak a háztartások. Így előzetes várakozásaim alapján arra a kutatási kérdésre kerestem a választ, hogy a nyugdíjkorhatárt elérő 65-80 éves korosztályban megfigyelhetö-e, hogy a válaszadók kevésbé kockázatos portfóliókat választanak, mint a fiatalabbak.

A leíró statisztikák alapján megfigyeltem, hogy a részvényeket nem tartalmazó portfóliókat választók esetében a 65-80 éves korosztály aránya 9,3\%-al nagyobb, mint a részvényeket is tartalmazó portfóliókat választók esetében. Ez a különbség 1\%-os szinten szignifikáns. Ezután egy ordinális logisztikus regressziós modell segítségével vizsgáltam meg a portfólió választási szokásokban megfigyelhetö különbségeket az életciklus szerint az iskolai végzettség és a kockázati magatartás függvényében. A modell eredményei megmutatták, hogy az iskolai végzettség és a kockázati magatartás hatásait kiszürve a 65-80 éves korosztályhoz képest a fiatalabb korosztályok szignifikánsan nagyobb valószínúséggel választanak kockázatosabb portfóliókat. Míg a 40-49 éves korosztályban $42,9 \%$ annak a valószínűsége, hogy a válaszadók részvényeket nem tartalmazó portfóliókat választanak, addig a 65-80 éves korosztályban 60,5 ez a valószínúség. Ezen felül azt is megmutattam, hogy a felsőfokú végzettséggel rendelkezők körében a 65-80 éves korosztály nagyobb valószínüséggel választ kevésbé kockázatos portfóliókat, mint a fiatalabbak. A modellbecslés eredményei is megerősítették azt a megállapítást, miszerint a 65-80 éves korosztály aránya szignifikánsan magasabb a részvényeket nem tartalmazó portfóliókat választók körében. Az iskolai végzettség és kockázati magatartás függvényében a részvényeket nem tartalmazó portfóliókat választók körében a 65-80 éves korosztály aránya 13,4-al nagyobb, amely különbség 1\%-os szinten szignifikáns.
$\mathrm{Az}$ eredmények alapján kutatási kérdésem vonatkozásában levonható a következtetést, hogy a magyar háztartások esetében a nyugdíjkorhatárt elérő 65-80 éves korosztályban a válaszadók nagyobb valószínűséggel választanak kevésbé kockázatos portfóliókat a fiatalabb korosztályokhoz képest. Ez az empirikus megfigyelés a magyar háztartások vonatkozásában iránymutatást jelent a portfólió választás életciklus elméletének nyugdijkorhatárt követő életszakaszaira. 


\section{IRODALOMJEGYZÉK REFERENCES}

Alan, S. (2006), "Entry costs and stock market participation over the life cycle", Review of Economic Dynamics, 9(4), pp.588-611 DOI: 10.1016/j.red.2006.06.003

Alhenawi, Y. \& Elkhal, K. (2013), "Financial literacy of US households: Knowledge vs. longterm financial planning", Financial Services Review, 22, 211-44

Ameriks, J. \& Zeldes, S. (2004), "How do Household Portfolio Shares Vary with Age?", Working paper, Columbia University

Arano, K., Parker, C. \& Terry, R. (2010), “Gender-based risk aversion and retirement asset allocation", Economic Inquiry, 48(1), 147-155 DOI: 10.1111/j.1465-7295.2008.00201.x

Bagliano, F., Fugazza, C. \& Nicodano, G. (2017), "A Life-Cycle Model with Unemployment Traps", Working papers 014, University of Torino

Balogh E., Kékesi Zs., Sisak B. (2019), „A háztartások befektetési döntéseinek vizsgálata nemzetközi adatokon", Hitelintézeti Szemle, 18(1) 61-90 DOI: 10.25201/HSZ.18.1.6190

Bateman, I. \& Munro, A. (2005), "An experiment on risky choice amongst households", The Economic Journal, 115(502), C176-C189 DOI: 10.1111/j.0013-0133.2005.00986.x

Benzoni, L., Collin-Dufresne, P. \& Goldstein, R. S. (2007), "Portfolio Choice over the Life-Cycle when the Stock and Labor Markets Are Cointegrated", The Journal of Finance, 62(5), 2123 2167 DOI: $10.1111 / j .1540-6261.2007 .01271 . x$

Bertocchi, G., Brunetti, M. \& Torricelli, C. (2014), "Who holds the purse strings within the household? the determinants of intra-family decision making", Journal of Economic Behavior \& Organization, 101, 65-86 DOI: 10.1016/j. jebo.2014.02.012

Boldizsár A., Kékesi Zs., Kóczián B., Sisak B. (2016), „A magyar háztartások vagyoni helyzete a HFCS felmérés alapján", Hitelintézeti Szemle, 15(4), 115-150

Campanale, C., Fugazza, C. \& Gomes, F. (2015), "Life-Cycle Portfolio Choice with Liquid and Illiquid Financial Assets", Journal of Monetary Economics, 71, 67-83 DOI: 10.1016/j.jmoneco.2014.11.008

Campbell, J. Y. (2006), "Household finance", The Journal of Finance, 61(4), 1553-1604 DOI: 10.1111/j.1540-6261.2006.00883.x

Catherine, S. (2019), "Countercyclical Labor
Income Risk and Portfolio Choices over the Life-Cycle", HEC Paris Research Paper, No. FIN-2016-1147

Choi, J. J. \& Robertson, A. Z. (2020), "What Matters to Individual Investors? Evidence from The Horse's Mounth", The Journal of Finance, 75(4), 1965-2020 DOI: 10.1111/jofi.12895

Clark, R., Lusardi, A. \& Mitchell, O. S. (2017), "Financial knowledge and 401 (k) investment performance: A case study", Journal of Pension Economics and Finance, 16(3), 324-347 DOI: $10.1017 / \mathrm{s} 1474747215000384$

Cocco, J., Gomes, F. \& Maenhout, P. (2005), "Consumption and portfolio choice over the life cycle", Review of Financial Studies, 18(2), 491-533 DOI: 10.1093/rfs/hhi017

Cooper, R. \& G. Zhu. (2016), "Household finance over the life-cycle: What does education contribute?", Review of Economic Dynamics, 20, 63-89 DOI: 10.1016/j.red.2015.12.001

Curcuru, S., Heaton, J., Lucas, D. \& Moore, D. (2010), Heterogeneity and portfoliochoice: Theory and evidence. In Handbook of Financial Econometrics: Tools and Techniques, Elsevier, $337-382$

Dimmock, S.G. \& Kouwenberg, R. (2010), "Loss-aversion and household portfolio choice", Journal of Empirical Finance, 17(3), 441-459 DOI: 10.1016/j.jempfin.2009.11.005

Elder, H. W. \& Rudolph, P. M. (2003), "Who makes the nancial decisions in the households of older americans?", Financial Services Review, 12(4)

Fagereng, A., Gottlieb, C. \& Guiso, L. (2017), "Asset Market Participation and Portfolio Choice over the Life-Cycle", The Journal of Finance, 72(2), 705-750 DOI: 10.1111/ jofi. 12484

Flinn, C. J., Todd, P. E. \& Zhang, W. (2018), "Personality traits, intra-household allocation and the gender wage gap", European Economic Review, 109, 191-220 DOI: 10.1016/j.euroecorev.2017.11.003

Friedberg, L. \& Webb, A. (2006), "Determinants and consequences of bargaining power in households. Technical report", National Bureau of Economic Research, DOI: 10.3386/w12367

Gomes, F., Haliassos, M. \& Ramadorai, T. (2020), "Household Finance", Journal of Economic Literature, Forthcoming, https://ssrn.com/ abstract $=3549863$

Gomes, F. \& Michaelides, A. (2005), "Optimal Life-Cycle Asset Allocation: Understanding the Empirical Evidence", The Journal of Finance, 60(2), 869-904 DOI: 10.1111/j.15406261.2005.00749.x 
Gu, R., Peng, C. \& Zhang, W. (2019), Risk Attitude and Portfolio Choice: An Intra-household Perspective.

Guillemette, M., Finke, M. S. \& Gilliam, J. (2012), "Risk Tolerance Questions to Best Determine Client Portfolio Allocation Preferences", Journal of Financial Planning, 25(5), 36-44

Jia, D., Li, R., Bian, S. \& Gan, C. (2019), "Financial Planning Ability, Risk Perception and Household Portfolio Choice", Emerging Markets Finance and Trade, 57(8), 2153-2175 DOI: 10.1080/1540496x.2019.1643319

Johnston, D. W., Kassenboehmer, S. C. \& Shields, M. A. (2016), "Financial decisionmaking in the household: Exploring the importance of survey respondent, health, cognitive ability and personality", Journal of Economic Behavior \& Organization, 132, 42-61 DOI: 10.1016/j. jebo.2016.09.014

Kuti M., Schepp Z. (2020), „Az idősödő társadalom és a kockázati attitüd”, Pénzügy Szemle, 2020(4), 457-471. DOI: 10.35551/PSZ_2020_4_1

Poterba, J. \& Samwick, A. A. (1997), "Household Portfolio Allocation Over the Life Cycle", NBER Working Paper 6185, National Bureau of Economic Research, DOI: 10.3386/w6185

Posza A. (2019), Az öregkor és az öregedés tudományelméleti megközelítései. In: Kuti M. (Szerk.): XIII. Pécsi Pénzügyi Napok - Új kihivások és lehetöségek: Pénzügykutatás, oktatás, szakma. Pécs: PTE KTK, 74-82.

Smith, J. P., McArdle, J. J. \& Willis, R. (2010), "Financial decision making andcognition in a family context", RAND Working Paper, DOI: $10.7249 /$ wr785

Ulbert J. (2005), „Hasznossági függvények és kockázati attitűd", Szigma, XXXVI. (2005) 1-2

Ulbert J., Csanaky A. (2004), „Kockázatészlelés és kockázati magatartás", Közgazdasági Szemle, LI ( március), 235-258
Van Rooij, M., Lusardi, A. \& Alessie, R. (2011), "Financial literacy and stock market participation", Journal of Financial Economics, 101(2), 449-472 DOI: 10.1016/j.jfineco.2011.03.006

Vasvári Tamás (2015), „Kockázat, kockázatészlelés, kockázatkezelés - szakirodalmi áttekintés", Pénzügyi Szemle, 2015/1.

Vissing-Jorgensen, A. (2002), "Limited Asset Market Participation and the Elasticity of Intertemporal Substitution", Journal of Political Economy, 110(4), 825-853 DOI: 10.1086/340782

Yilmazer, T. \& Lich, S. (2015), "Portfolio choice and risk attitudes: a household bargaining approach", Review of Economics of the Household, 13(2), 219-241 DOI: 10.1007/s11150013-9207-8

Yilmazer, T. \& Lyons, A. C. (2010), "Marriage and the allocation of assets in women's dened contribution plans", Journal of Family and Economic Issues, 31(2), 121-137 DOI: 10.1007/ s10834-010-9191-6

Zhan, J. C. (2015), "Who holds risky assets and how much? An empirical study based on the HFCS data", Empirica, 42(2), 323-370 DOI: 10.1007/s10663-015-9295-1 


\section{MELLÉKLETEK APPENDIX}

1. táblázat: Portfólió választást megragadó kérdés

Table 1. Question concerning the portfolio choice

B5. Az alábbi 7 portfólió (befektetési csomag) eltérö arányban tartalmaz magas, átlagos, illetve alacsony kockázat/hozam jellemzőkkel rendelkező befektetéseket. Interjúkészítő, add át az 1. számú kártyát, ha kell, magyarázd el! Ön melyiket választaná?

\begin{tabular}{|c|c|c|c|}
\hline Portfólió & $\begin{array}{l}\text { Magas kockázat/ } \\
\text { hozam (részvény) }\end{array}$ & $\begin{array}{l}\text { Közepes kockázat/ } \\
\text { hozam (kötvény) }\end{array}$ & $\begin{array}{l}\text { Alacsony kockázat/hozam } \\
\text { (ingatlan) }\end{array}$ \\
\hline 1 & $0 \%$ & $0 \%$ & $100 \%$ \\
\hline 2 & $0 \%$ & $30 \%$ & $70 \%$ \\
\hline 3 & $10 \%$ & $40 \%$ & $50 \%$ \\
\hline 4 & $30 \%$ & $40 \%$ & $30 \%$ \\
\hline 5 & $50 \%$ & $40 \%$ & $10 \%$ \\
\hline 6 & $70 \%$ & $30 \%$ & $0 \%$ \\
\hline 7 & $100 \%$ & $0 \%$ & $0 \%$ \\
\hline
\end{tabular}

Forrás: saját szerkesztés

2. táblázat: A kockázati magatartást megragadó kérdések

Table 2. Questions about risk tolerance

\begin{tabular}{|c|c|c|}
\hline Kérdés & Lehetséges válaszok & A kérdés célja \\
\hline $\begin{array}{l}\text { B1. Mit gondol, eddigi } \\
\text { fontosabb pénzügyi } \\
\text { döntései során inkább } \\
\text { a lehetséges vesztesé- } \\
\text { gekre, vagy inkább az } \\
\text { elérhető nyereségekre } \\
\text { figyelt? }\end{array}$ & $\begin{array}{l}\text { 1- Mindig a lehetséges veszteségekre. } \\
2 \text { - Általában a lehetséges veszteségekre. } \\
3 \text { - Általában az elérhető nyereségekre. } \\
4 \text { - Mindig az elérhető nyereségekre }\end{array}$ & $\begin{array}{l}\text { Kockázati magatartás mérése a } \\
\text { veszteségkerülés mértéke alap- } \\
\text { ján }\end{array}$ \\
\hline $\begin{array}{l}\text { B2. Tegyük fel, hogy } \\
\text { vannak befektetései, és } \\
\text { befektetéseinek értéke } \\
\text { folyamatosan változik. } \\
\text { Mit gondol, ha befek- } \\
\text { tetéseinek összértéke } \\
\text { csökkenni kezdene, a } \\
\text { csökkenés milyen mér- } \\
\text { tékénél kezdené magát } \\
\text { kényelmetlenül érezni? }\end{array}$ & $\begin{array}{l}1-\text { Bármekkora csökkenés kényelmetle- } \\
\text { nül érintene. } \\
2-10 \% \\
3-20 \% \\
4-33 \% \\
5-50 \% \\
6-\text { több mint } 50 \%\end{array}$ & $\begin{array}{l}\text { Kockázati magatartás mérése a } \\
\text { veszteségkerülés mértéke alap- } \\
\text { ján }\end{array}$ \\
\hline $\begin{array}{l}\text { B3. Mit gondol, mek- } \\
\text { kora kockázatot vállalt } \\
\text { korábbi pénzügyi dönté- } \\
\text { sei során? }\end{array}$ & $\begin{array}{l}\text { 1 - Nagyon kicsit } \\
2 \text { - Kicsit } \\
3 \text { - Átlagos mértéküt } \\
\text { 4-Nagyot } \\
5 \text { - Nagyon nagyot }\end{array}$ & $\begin{array}{l}\text { Kockázati magatartás mérése } \\
\text { önértékelés alapján }\end{array}$ \\
\hline $\begin{array}{l}\text { B4. Ha lesznek ilyenek, } \\
\text { mekkora kockázatot } \\
\text { tervez vállalni pénzügyi } \\
\text { döntései során a jövő- } \\
\text { ben? }\end{array}$ & $\begin{array}{l}1 \text { - Nagyon kicsit } \\
2 \text { - Kicsit } \\
3 \text { - Átlagos mértéküt } \\
4 \text { - Nagyot } \\
\text { - Nagyon nagyot }\end{array}$ & $\begin{array}{l}\text { Kockázati magatartás mérése } \\
\text { önértékelés alapján }\end{array}$ \\
\hline
\end{tabular}

Forrás: saját szerkesztés 
3. táblázat: Szociológiai tényezőket megragadó kérdések Table 3. Questions concerning sociological factors

\begin{tabular}{|c|c|c|}
\hline Kérdés & Lehetséges válaszok & A kérdés célja \\
\hline $\begin{array}{l}\text { SZ1. Hány éves Ön? Ezt azért } \\
\text { kell megkérdeznem, hogy tud- } \\
\text { jam, kitölthetem-e Önnel az } \\
\text { interjút. }\end{array}$ & $\begin{array}{l}1-18-29 \\
2-30-39 \\
3-40-49 \\
4-50-64 \\
5-65-80\end{array}$ & Kohorszok meghatározása \\
\hline H1. A válaszadó neme: & $\begin{array}{l}1-\text { férfi } \\
2-\text { nö }\end{array}$ & Nem meghatározása \\
\hline $\begin{array}{l}\mathrm{H} 2 . \mathrm{Mi} \text { az Ön legmagasabb } \\
\text { befejezett iskolai végzettsége? }\end{array}$ & $\begin{array}{l}1 \text { - legfeljebb } 8 \text { általános } \\
2 \text { - szakmunkásképző, szakiskola } \\
3 \text { - érettségi } \\
4 \text { - felsőfokú végzettség } \\
0 \text { - NV }\end{array}$ & Iskolai végzettség meghatározása \\
\hline $\begin{array}{l}\text { H3b. Az alábbiak közül melyik } \\
\text { csoportba sorolná háztartása } \\
\text { egy före jutó havi nettó jöve- } \\
\text { delmét? Értsen ide minden } \\
\text { bevételt, tehát például a külön- } \\
\text { féle járadékokat is! Kérdezö! } \\
\text { Add át a jövedelem-kártyát! }\end{array}$ & $\begin{array}{l}1-32000 \mathrm{Ft}-\text { nál kevesebb } \\
2-32001-65000 \mathrm{Ft} \\
3-65001-90000 \mathrm{Ft} \\
4-90001-114000 \mathrm{Ft} \\
5-114001-158000 \mathrm{Ft} \\
6-\text { több, mint } 158001 \mathrm{Ft} \\
0-\mathrm{NT} / \mathrm{NV}\end{array}$ & Jövedelmi helyzet meghatározása \\
\hline $\begin{array}{l}\text { H5. Önt is beleértve hányan } \\
\text { élnek az Önök háztartásában? }\end{array}$ & fó & Egy háztartásban élők száma \\
\hline
\end{tabular}

Forrás: saját szerkesztés 
Tóth-Pajor Ákos, egyetemi tanársegéd toth-pajor.akos@ktk.pte.hu

Pécsi Tudományegyetem Közgazdaságtudományi Kar

\section{Portfolio choice for old age in Hungary}

\section{THE AIMS OF THE PAPER}

In this study I analyse the portfolio choice of the hungarian households after retirement. I seek to find out what preferences drive the portfolio choice in the 65-80 year old cohort, because the life-cycle theory of portfolio choice leads to ambiguous conclusions after retirement.

\section{METHODOLOGY}

To answer my research question I used an ordinal logistic regression model to analyse the portfolio choice over the life-cycle according to the education and the risk attitude of the respondents.

\section{MOST IMPORTANT RESULTS, NEW FINDINGS}

I found that after eliminating the impact of the education and the risk attitude mebers of the $65-80$ year old cohort choose less risky portfolios with a higher probability than younger respondents. Furthermore, I showed that the proportion of the 65-80 year old cohort is significantly higher among those, who chose portfilios which do not include stocks.

\section{EMPIRICAL IMPLICATIONS OF THE RESEARCH}

The results highlight the preferences of the Hugarian households concerning the portfolio choice after retirement, thus it provide empirical proof which suplements the conclusions of the portfolio choice theory.

Keywords: portfolio choice, ageing, risk behavior 